\title{
The Impact of Market Orientation on Performance of Selected Hotels in Ondo State, Nigeria
}

\author{
Ajayi M. Oluwatoyin'1, Adeniji P. Olufunke1, Ighomereho 0. Salome² \\ ${ }^{1}$ Department of Transport and Tourism Studies, Redeemer's University, Ede, Osun State, Nigeria \\ ${ }^{2}$ Department of Economics and Business Studies, Redeemer's University, Ede, Osun State, Nigeria \\ Email: aduk1012@yahoo.com
}

How to cite this paper: Oluwatoyin, A.M., Olufunke, A.P. and Salome, I.O. (2018) The Impact of Market Orientation on Performance of Selected Hotels in Ondo State, Nigeria. Open Journal of Business and Management, 6, 616-631.

https://doi.org/10.4236/ojbm.2018.63047

Received: April 12, 2018

Accepted: June 11, 2018

Published: June 14, 2018

Copyright ( $) 2018$ by authors and Scientific Research Publishing Inc. This work is licensed under the Creative Commons Attribution International License (CC BY 4.0). http://creativecommons.org/licenses/by/4.0/

\begin{abstract}
Market orientation has been identified as a critical success factor for business performance. However, this relationship has not been adequately investigated in the hotel industry especially in Nigeria. Consequently, the purpose of this study is to investigate the impact of market orientation practices on performance of selected hotels in Akure, Ondo State, Nigeria. The study further investigates if the age or size of a hotel influences market orientation practices. To achieve the objectives of the study, a cross-sectional research design was adopted. Data was collected with the aid of questionnaire from 68 hotels. The findings indicate that market orientation has impact on the performance of hotels. It was also found that the size of a hotel has no influence on market orientation practices but it is influenced by the age of the hotel. Therefore, the study provides new insights into the understanding of market orientation practices in the hotel industry.
\end{abstract}

\section{Keywords}

Market Orientation, Business, Performance, Hotel, Nigeria

\section{Introduction}

Most previous studies on market orientation have reported a positive relationship between market orientation and business performance [1] [2] [3] [4]. This has been attributed to the view that in contemporary business environment, customers prefer companies that can deliver coordinated long-lasting satisfaction and value through the products they offer [5]. As such, there is need for businesses to continuously generate information about the current and future 
customer needs and wants, disseminate this information to all departments and respond to changes promptly.

Moreover, in today's highly competitive global market, top managers strive to improve their organizational effectiveness through execution of organizational strategies or capabilities that are linked to better performance. As a result, market orientation becomes a crucial strategy or capability of an organization to stay competitive in the current uncertain business environment [6].

Despite the importance of market orientation to business success, systematic inquiries to gain a deeper understanding of the construct began, following the pioneering work of [7] and [8]. Since then, there have been several researches on market orientation and performance. The studies have attempted to assess the association of market orientation with different performance measures such as profitability [9] [10] [11] [12], market share [13] [14], new product success [15] and customer satisfaction [16]. The findings indicated that market orientation is positively related to business performance. However, relatively few researches have addressed, in the empirical sense, the proposition that the adoption of market orientation leads to improved performance in the hotel industry, especially in the Nigerian context. To fill this gap in the literature, the present study attempts to examine the current state of market orientation in the hotel industry. The specific objectives are to:

1) Determine if there is a significant relationship between market orientation and performance of hotels in Akure, Ondo State, Nigeria.

2) Ascertain if the size of a hotel affects market orientation practices in Akure, Ondo State, Nigeria.

3) Examine if the age of a hotel affects market orientation practices in Akure, Ondo State, Nigeria.

\section{Literature Review}

\subsection{Market Orientation}

Market orientation is a managerial decision-making practice with a commitment shared within the organization [17]. Market oriented firms are defined by their superior understanding of customers' current and future needs and by their ability to offer solutions to those needs better than competitors [18]. Market orientation has been explained by [8] with three dimensions: competitor orientation, customer orientation and inter-functional coordination. However, [7] stated that market orientation comprises three components: intelligence gathering, intelligence dissemination and responsiveness.

Whereas [8] opined that market orientation is an organizational culture based on behavior, norms and values, [7] emphasized market orientation as a marketing concept. Several researchers [19] [20] [21] mentioned that market orientation as defined by [8] has strong validity and reliability, as well as being able to sufficiently conceptualize the construct to capture the customers' value. However, [22] criticized the market orientation measure on the grounds that it adopts a 
focused view of markets by emphasizing customers and competition as compared with a view that focuses on these two stakeholders and additional factors that drive customer needs and expectation (e.g. technology, regulation). Also, it did not tap the speed with which market intelligence is generated and disseminated within an organization and it includes a number of items that do not tap specific activities and behaviors that represent market orientation.

It has been noted that, the notion of market orientation suggested by both [7] and [8] are alike in some ways. In both cases, the scholars viewed market orientation as a continuous variable, focusing on obtaining information from competitors and customers and emphasizing the significance of collective efforts in creating value for customers [21].

Market Orientation has also been defined as the way businesses manage all their multiple stakeholders and examine the extent to which businesses behave or are inclined to behave, in accordance with the marketing concept [23]. Market orientation can also be described as a means to ensure the timely identification and satisfaction of customer needs [4] [24]. Firms following the market orientation strategy go along with an open system which allows them to have an active interaction with the external environment while firms that remain focused on their internal systems, try to develop a defensive system against environmental shocks [8]. Market orientation thus involves the process of integrating activities with emphasis on delivering superior customer value rather than focusing on costs [7] [25]. Different theoretical contributions and various empirical studies have led to the accepted view that the components and themes of market orientation include customer orientation, competitor orientation and inter-functional orientation [26] [27] as depicted in Figure 1.

\subsection{Customer Orientation}

Customer orientation is an organizational culture that considers the present and potential customers' needs and wants, constantly producing value [8] [28]. Customer orientation comprises a set of beliefs that the customer should be given priority in the organization [4] [13]. Also, all the strategies should be developed in such a way that they deliver superior value to customers. This means that customer-oriented organizations get information about customers' needs and wants for the present and future to provide superior value-added offerings [29].

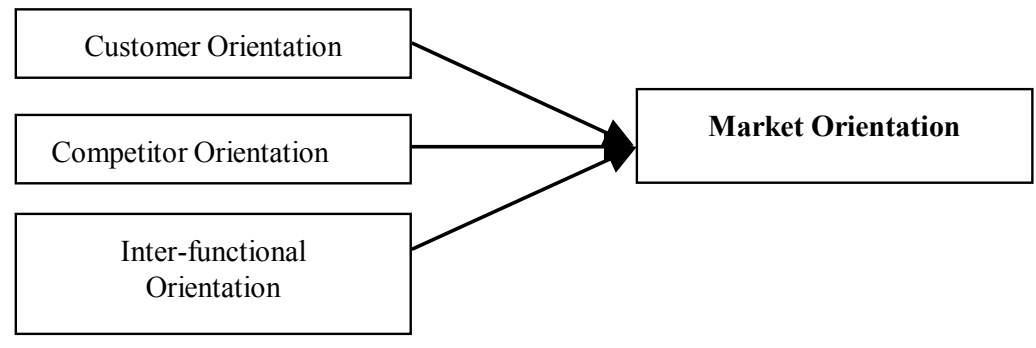

Figure 1. Market orientation and its dimensions. Source: Designed by the researchers based on previous studies (2017). 
This will allow the organization to share the information about their customers with all the staff, with the aim of continuously getting market intelligence to serve their customers better.

Market intelligence not only pertains to monitoring customer's needs and preferences, but also includes an analysis of how customers might be affected by factors such as government regulation, technology, competitors and other environmental forces which in turn, deliver superior business performance [7] [30].

\subsection{Competitor Orientation}

Competitor orientation is monitoring the organization's current and predicted future competitors to develop awareness of their information and strategies [31] [32]. Competitor orientation refers to the understanding of short term strengths and weakness and long term capabilities and strategies of competitors. Competitor-oriented organizations develop a comprehensive evaluation of targeted and possible rivals and utilize the substantial awareness to beat the rivals as well as achieve sustainable competitive advantage and performance [33].

\subsection{Inter-Functional Orientation}

This is the behavioral component of market orientation which is based on the customer and competitor's information and comprises the business coordinated efforts, typically involving more than marketing department to create superior value for the buyers [7]. Hence, it relates to the entire business and not merely a single department. Creating value for buyers is more than marketing function. A seller's creation of value for buyers is analogous to a symphony orchestra in which the contribution of each subgroup is tailored and integrated by a conductor with a synergistic effect. The coordinated integration of the organization's resources in creating superior value for buyers obviously is tied closely to customer and competitor orientation.

Given the multidimensional nature of creating superior value for customers, marketing interdependence with other business function must be symmetrically incorporated in a business marketing strategy. Thus, achieving effective inter-functional coordination requires among other things, an alignment of the functional areas incentives and the creation of inter-functional dependency so that each area perceives its own advantage in cooperation closely with the others [32].

\subsection{Empirical Review}

[1] conducted a study on the effect of market orientation on organizational performance. Results from a sample of 162 manufacturing and service firms provided support for a strong positive relationship between market orientation and growth in overall revenue, return on capital, success of new products and services, ability to retain customers, and success in controlling operating expenses. The study found that competitive hostility, suppliers' power and market turbu- 
lence did not moderate the market orientation and performance relationship.

[2] examined market orientation and business performance among SMEs in Ghana. The results showed that the development of market orientation in SMEs rests more on the attitude of owners/managers and that market orientation leads to superior performance under ceaseless competitive conditions.

[34] focused on the internal process through which market orientation influences performance in export markets and developed a model of market orientation-marketing capabilities-competitive advantages-performance relationships. It was found that marketing capabilities mediate the market orientation and performance relationship, while competitive advantages partially mediate the marketing capabilities and performance relationship.

[35] examined the relationship between market orientation and organizational performance with service quality as a moderator in the context of the hotel industry in Malaysia. The findings suggest that only competitor orientation dimension of market orientation was significantly related to organizational performance, whereas customer orientation and inter-functional coordination were not related. Also, service quality was found to have moderated the relationship between market orientation and performance of the hotels in Malaysia.

[3] investigated the impact of market orientation on business performance in knowledge-intensive companies. The findings showed that market orientation has a positive impact on financial and non-financial business performance in knowledge-intensive industries. Based on the findings, the authors argued that it is important for hi-tech companies to improve their performance by implementing market orientated strategies, putting emphasis in conducting effective market research and be strong in customer and competitor orientation.

[4] investigated the relationship between market orientation and performance in the context of small and medium sized enterprises (SMEs). It was found that market orientation has significant positive influence on performance. Thus, the authors suggested that SMEs owners/ managers should create and maintain the market orientation culture in order to attain sustainable superior firm performance.

The previous studies reviewed indicate that the relationship between market orientation and performance has been investigated extensively and there is a general agreement that market orientation influences performance. However, relatively few studies have addressed the relationship between market orientation and performance in the hotel industry [35]. Most of the studies investigated manufacturing and service firms [1]; SMEs [2] [4]; export market [34]; knowledge-intensive companies [3]. Moreover, the studies did not investigate the influence of size and age of a firm on the adoption of market orientation practices. The literature reveals that there is need to move beyond the market orientation and performance relationship to some of the factors that may distinguish a market oriented firm and a non-market oriented firm. Although, there may be several factors responsible for the differentiation, this study focused on size and age of the hotels. 


\section{Method}

\subsection{Population of the Study}

The population of the study comprised of members of staff in the hotels operating in Akure, Ondo State, Nigeria. Akure was chosen because it is the largest city and capital of Ondo State. Also, most of the hotels are located in Akure [36]. The study was spread amongst all the four categories of hotels existing in the study area using star rating method.

\subsection{Sample Size}

The sampling frame from which the sample of hotels was drawn, was obtained from a database maintained in [37]. The database indicates that there are 82 hotels in Akure with star rating categorization ranging from 1 star to 4 stars. The four categories of hotels based on star rating are in the following proportions: 1 Star hotel (39), 2 Star hotel (37), 3 Star hotel (4) and 4 Star hotel (2).

In order to effectively determine a representative sample of the entire population of hotels in Akure metropolis, the sample size was determined using [38] formula as follows:

$$
n=N /\left(1+N e^{\wedge} 2\right)
$$

where

$$
\begin{aligned}
& \mathrm{n}=\text { Corrected sample size; } \\
& \mathrm{N}=\text { Population size; } \\
& \mathrm{e}=\text { Margin of error }(\mathrm{MoE})=0.05 \text {. }
\end{aligned}
$$

This gives 68, thus, the sample size was put at 68 .

\subsection{Sampling Technique and Procedure}

The study employed stratified sampling technique to select the 68 hotels from the 82 hotels in the study area. To allocate the sample size of 68 to the sample groups, Bourley's proportional allocation formula was employed. It is given as:

$$
n b=n(n) / N
$$

where;

$\mathrm{nb}=$ Bourley's formula;

$n=$ Element within the sample frame, i.e. number allocated to star rating;

$\mathrm{n}=$ Sample or proportion of the universe used for the study (total sample size);

$\mathrm{N}=$ Population of the study.

Based on the results, the sample selected include1 Star hotel [32], 2 Star hotel [30], 3 Star hotel [4] and 4 Star hotel [2].

\subsection{Instrumentation}

Questionnaire was used to collect data for the study. It comprised of three sections. Section A is on hotel profile, Section B is on market orientation while Section $\mathrm{C}$ is on hotel performance. The market orientation practices by the hotels were measured using the following: 
1) Customer's feedback form-which are dropped in each room for guest to fill in order to obtain information on the performance of the hotel and the expectation of the guest.

2) Suggestion box-similar to i. above but is positioned at strategic locations within the hotel to gather information for improvement purpose.

3) Use of Social Media-Facebook, Twitter, Skype etc. are other means through which guests freely communicate their experiences and expectations to hotels that open account on such platforms for the purpose of feedback.

4) Online booking-many of the hotels make use of web page to reach their targeted audience. booking.com, hotel.ng. Jumai, Kayah, wakanow.com are some of the media through which some of these hotel sell their products.

5) Complimentary breakfast.

6) Free daily Newspaper.

7) Free Internet Services.

8) Promotions - such as book four nights get one night free, book 5 rooms at discounted rate are some of the marketing strategies used by hotels.

9) Recognition of outstanding staff/customers to boost their morale for more dedication is another strategies used.

The parameters used in the analysis of the performance of the hotels which are based on the rating scale are repeat customer's patronage, retention of old customers, friendliness to customer, enhanced patronage and customer's satisfaction.

\section{Data Analysis}

Overall, 581 copies of the questionnaire were administered in the 68 hotels selected. However, 500 copies of the questionnaire were retrieved and used for the analyses. 24 copies of the questionnaire administered were eliminated due to incomplete responses while 57 were not returned. The data obtained were presented in tables and analyzed by frequency counts and percentages. Percentage was used to examine the profile of the hotels, the personal characteristics of respondents and to check the disparity in responses among different group of respondents on effect of market orientation on hotel performance. In addition, correlation analysis was used to test the relationship between the variables.

Table 1 shows that the frequency of hotels below 5 years age of establishment is $255 \%$ or $51.0 \%$ percent, 165 or 33.0 percent were between 5 to 10 years age of establishment, 60 or 12.0 percent were between the age of 11 to 20 years and 20 or 4.0 percent were over 21 years of existence in the industry. These implies that almost half of the hotels were over the age of 5 years and thus their maturity level would richly enhance the validity of the responses for this study.

Table 2 shows the frequency distribution by size of the hotels in terms of number of rooms. $293 \%$ or $58.6 \%$ percent of the hotels had less than 50 rooms, 107 or 21.4 percent had between 50 to 100 rooms, 70 or 14.0 percent had between 101 to 150 rooms, $20 \%$ or $4.0 \%$ had between $151-200$ rooms and 10 or 
Table 1. Year of establishment of hotel.

\begin{tabular}{ccc}
\hline Age of Hotel & Frequency & Percent (\%) \\
\hline Below 5 years & 255 & 51 \\
$5-10$ years & 165 & 33 \\
$11-20$ years & 60 & 12 \\
21 and above & 20 & 4 \\
Total & 500 & 100 \\
\hline
\end{tabular}

Source: Authors' fieldwork (2017).

Table 2. Size of hotel.

\begin{tabular}{ccc}
\hline Size & Frequency & Percent \\
\hline Below 50 & 293 & 58.6 \\
$50-100$ & 107 & 21.4 \\
$101-150$ & 70 & 14.0 \\
$151-200$ & 20 & 4.0 \\
201 and above & 10 & 2.0 \\
Total & 500 & 100 \\
\hline
\end{tabular}

Source: Authors' fieldwork (2017).

2.0 percent had 201 and above rooms. This seems to suggest that majority of the hotels had less than 50 rooms.

Table 3 shows the frequency distribution by gender. Majority of the respondents were female that is $304 \%$ or $60.8 \%$ while $196 \%$ or $39.2 \%$ were male. This may be attributed to the belief that females find hotel jobs less stressful and adaptable to their nature than their male counterpart and so they readily take up appointment in hotels.

Table 4 shows that the frequency of respondents that have served 0 - 5 years in the hotels studied was 224 or 44.8 percent, 216 respondents or 43.2 percent had served for between 6 - 10 years in hotel while 60 respondents or 12.0 percent of the respondents had being in the hotel for 11 years and above. This shows that majority of the respondents have spent more than 5 years with their respective hotels and as such, they are at vintage position to give unbiased and reliable information that enriched the findings of this study.

Table 5 shows the frequency, percentage and mean of the responses on the ways market orientation has affected hotel performance in terms of repeat customer's patronage, retention of old customers, friendliness to customers, enhanced patronage and customer satisfaction. Majority of the respondents with a frequency of $252 \%$ or $50.4 \%$ responded that market orientation has affected their performance in terms of customer satisfaction in a very large extent, follow by enhance patronage 215 (43\%). The least was Friendliness of customer 99 (19.8\%) but on the average, the respondents agreed to all statements that market orientation 
Table 3. Distribution by gender of the respondents.

\begin{tabular}{ccc}
\hline Gender & Frequency & Percent \\
\hline Male & 196 & 39.2 \\
Female & 304 & 60.8 \\
Total & $\mathbf{5 0 0}$ & $\mathbf{1 0 0}$ \\
\hline
\end{tabular}

Source: Authors' fieldwork (2017).

Table 4. Years of work experience in the hotel.

\begin{tabular}{ccc}
\hline Work Experience & Frequency & Percent \\
\hline 0 - 5 years & 224 & 44.8 \\
$6-10$ years & 216 & 43.2 \\
11 years \& above & 60 & 12.0 \\
Total & 500 & 100 \\
\hline
\end{tabular}

Source: Authors' fieldwork (2017).

Table 5. Effects of market orientation on performance of hotel in Akure, Ondo State.

\begin{tabular}{|c|c|c|c|c|c|c|c|c|c|c|c|c|c|c|}
\hline \multirow{2}{*}{$\mathbf{S} / \mathbf{N}$} & \multirow{2}{*}{ Variables } & \multicolumn{2}{|r|}{1} & \multicolumn{2}{|c|}{2} & \multicolumn{2}{|c|}{3} & \multicolumn{2}{|c|}{4} & \multicolumn{2}{|c|}{5} & \multicolumn{2}{|c|}{6} & \multirow{2}{*}{ Mean } \\
\hline & & $f$ & $\%$ & $f$ & $\%$ & $f$ & $\%$ & $F$ & $\%$ & $f$ & $\%$ & $F$ & $\%$ & \\
\hline 1 & $\begin{array}{l}\text { Repeat } \\
\text { customer's } \mathrm{Pa}- \\
\text { tronage }\end{array}$ & 127 & 25.4 & 215 & 43 & 67 & 13 & 43 & 8.6 & 25 & 5 & 23 & 4.6 & 4.61 \\
\hline 2 & $\begin{array}{l}\text { Retention of old } \\
\text { customers }\end{array}$ & 195 & 39 & 192 & 38 & 64 & 13 & 36 & 7.2 & 10 & 2.0 & 3 & 0.6 & 5.03 \\
\hline 3 & $\begin{array}{c}\text { Friendliness to } \\
\text { customer }\end{array}$ & 99 & 19.8 & 140 & 28 & 135 & 27 & 83 & 21 & 22 & 4.4 & 21 & 4.2 & 4.30 \\
\hline 4 & $\begin{array}{l}\text { Enhanced } \\
\text { patronage }\end{array}$ & 215 & 43 & 192 & 38 & 35 & 7 & 16 & 3.2 & 28 & 5.6 & 14 & 2.8 & 5.02 \\
\hline 5 & $\begin{array}{l}\text { Customer's } \\
\text { satisfaction }\end{array}$ & 252 & 50.4 & 181 & 36 & 20 & 4 & 18 & 3.6 & 17 & 3.4 & 12 & 2.4 & 5.19 \\
\hline
\end{tabular}

Source: Authors' fieldwork (2017). Keys: 1 = To a very large extent; 2 = To a large extent; 3 = Undecided; 4 = Often; 5 = Rarely; $6=$ Never. $\mathrm{f}=$ frequency; $\%$ = Percentage; $\bar{x}=$ Mean.

affect hotel performance in Akure. This is further confirmed by the mean response of (4.61, 5.03, 4.30, 5.02, and 5.19).

According to the results in Table 6, there is a significant positive correlation between market orientation and all the performance variables. There is a significant correlation between market orientation and customer satisfaction (0.762), Correlation of market orientation and retention of old customers (0.703), enhanced patronage (0.700) are also significant and positive while the correlation between market orientation and repeat customer patronage (0.549) and friendliness to customers (0.408) are moderate and positive.

Table 7 reveals the frequency, percentage and mean distribution of respondents on each of the assertion set out to examine the market orientation practices in selected hotels based on size. The addition of the mean value $(x)$ summa- 
ries indicate the strength of the respondents towards the statements, using a decision rule as thus: where $\left(\sum x>3.0\right)$, more respondents tended toward agreement and where $\left(\sum x<3.0\right)$, more respondents tended towards disagreement. The respondents were asked several statements on market orientation practices. Based on the size of the hotels, the overall sampled respondents agreed to these statements. The implication is that, the selected hotels have been practicing market orientation irrespective of the size of hotel. This is further supported by the mean of the responses 3.17 which tends towards agreement to the assertion that they practice market orientation.

On the relationship between market orientation and the age of a hotel (Table 8), out of the total sampled respondents, some of the respondents disagreed to the statements. The implication is that market orientation is influenced by the age of a hotel. This is further supported by the mean of the responses 1.32 which tends towards disagreement to the earlier assertion that they practice market orientation.

Table 6. Correlation analysis between market orientation and hotel performance.

\begin{tabular}{|c|c|c|c|c|c|c|}
\hline Hotel performance & $\begin{array}{l}\text { Repeat customer's } \\
\text { patronage }\end{array}$ & $\begin{array}{l}\text { Retention of old } \\
\text { customers }\end{array}$ & $\begin{array}{l}\text { Friendliness of } \\
\text { customer }\end{array}$ & $\begin{array}{l}\text { Enhanced } \\
\text { patronage }\end{array}$ & $\begin{array}{c}\text { Customer } \\
\text { satisfaction }\end{array}$ & $\begin{array}{c}\text { Market } \\
\text { orientation }\end{array}$ \\
\hline Repeat customer's patronage & 1 & & & & & \\
\hline Retention of old customers & $0.362^{\star}(0.000)$ & 1 & & & & \\
\hline Friendliness of customer & $0.469^{\star}(0.000)$ & $0.345^{\star}(0.000)$ & 1 & & & \\
\hline Enhanced patronage & $0.269^{*}(0.000)$ & $0.370^{*}(0.000)$ & $0.565^{\star}(0.000)$ & 1 & & \\
\hline Customer satisfaction & $0.349^{*}(0.000)$ & $0.298^{\star}(0.000)$ & $0.507^{\star}(0.000)$ & $0.476^{\star}(0.000)$ & 1 & \\
\hline Market orientation & $0.549^{*}(0.000)$ & $0.703^{\star}(0.000)$ & $0.408^{\star}(0.000)$ & $0.700^{*}(0.000)$ & $0.762^{\star}(0.000)$ & 1 \\
\hline
\end{tabular}

Source: Authors' fieldwork (2017). ${ }^{*}$. Correlation is significant at the 0.05 level (2-tailed).

Table 7. Market orientation practices with respect to hotel size.

\begin{tabular}{|c|c|c|c|c|c|c|c|c|c|c|c|}
\hline \multirow{2}{*}{ Variables } & \multicolumn{2}{|c|}{ Below 50 rooms } & \multicolumn{2}{|c|}{$50-100$ rooms } & \multicolumn{2}{|c|}{$101-150$ rooms } & \multicolumn{2}{|c|}{$151-200$ rooms } & \multicolumn{2}{|c|}{201 and above } & \multirow[b]{2}{*}{ Mean } \\
\hline & $f$ & $\%$ & $f$ & $\%$ & $f$ & $\%$ & $f$ & $\%$ & $f$ & $\%$ & \\
\hline Customer's feedback form & 27 & 17.4 & 11 & 9.6 & 12 & 10.1 & 8 & 6.6 & 5 & 6.8 & 0.28 \\
\hline Suggestion box & 11 & 7.2 & 14 & 12.3 & 25 & 21.0 & 5 & 4.1 & 8 & 11.1 & 0.35 \\
\hline Use of social media & 13 & 8.3 & 8 & 7.0 & 8 & 6.7 & 10 & 8.3 & 6 & 8.3 & 0.25 \\
\hline Online booking channel & 17 & 10.9 & 12 & 10.5 & 16 & 13.4 & 9 & 7.5 & 3 & 4.1 & 0.28 \\
\hline Complimentary breakfast buffet & 9 & 5.8 & 17 & 14.9 & 14 & 11.8 & 14 & 11.7 & 9 & 12.1 & 0.37 \\
\hline Free daily newspaper & 18 & 11.7 & 8 & 7.1 & 12 & 10.1 & 17 & 14.2 & 8 & 11.1 & 0.36 \\
\hline Free internet services & 16 & 10.4 & 4 & 3.5 & 1 & 0.8 & 31 & 25.8 & 11 & 15.1 & 0.41 \\
\hline Promotions & 17 & 10.9 & 12 & 10.5 & 6 & 5.0 & 5 & 4.2 & 8 & 11.1 & 0.24 \\
\hline Recognition & 12 & 7.8 & 10 & 8.7 & 17 & 14.3 & 12 & 10.1 & 9 & 12.1 & 0.35 \\
\hline Others (specify) & 15 & 9.6 & 18 & 15.9 & 8 & 6.8 & 9 & 7.5 & 6 & 8.2 & 0.28 \\
\hline Total & 155 & 100 & 114 & 100 & 119 & 100 & 120 & 100 & 73 & 100 & 3.17 \\
\hline
\end{tabular}

Source: Authors' fieldwork (2017). 
Table 8. Market Orientation practices adopted and the age of hotel.

\begin{tabular}{|c|c|c|c|c|c|c|c|c|c|}
\hline \multirow{3}{*}{$\begin{array}{c}\text { Statements } \\
\text { Market orientation practices adopted }\end{array}$} & \multicolumn{8}{|c|}{ Age of hotel } & \multirow[b]{3}{*}{ Mean } \\
\hline & \multicolumn{2}{|c|}{ Below 5 years } & \multicolumn{2}{|c|}{$5-10$ years } & \multicolumn{2}{|c|}{11 - 20 YEARS } & \multicolumn{2}{|c|}{21 and above } & \\
\hline & $f$ & $\%$ & $f$ & $\%$ & $f$ & $\%$ & $f$ & $\%$ & \\
\hline Customer's feedback form & 26 & 13.0 & 25 & 12.8 & 17 & 12.9 & 15 & 11.3 & 0.17 \\
\hline Suggestion box & 32 & 16.0 & 21 & 10.7 & 18 & 13.7 & 12 & 9.0 & 0.17 \\
\hline Use of social media & 20 & 10.0 & 13 & 6.6 & 13 & 9.9 & 10 & 7.6 & 0.11 \\
\hline Online booking channel & 8 & 4.0 & 17 & 8.7 & 6 & 4.6 & 13 & 9.7 & 0.09 \\
\hline Complimentary breakfast buffet & 52 & 26.0 & 48 & 24.6 & 18 & 13.7 & 8 & 6.0 & 0.25 \\
\hline Free daily newspaper & 10 & 5.00 & 18 & 9.3 & 13 & 9.9 & 16 & 12.0 & 0.11 \\
\hline Free internet services & 11 & 5.5 & 14 & 7.3 & 12 & 9.3 & 18 & 13.6 & 0.11 \\
\hline Promotions & 23 & 11.5 & 15 & 7.7 & 14 & 10.7 & 16 & 12.0 & 0.14 \\
\hline Recognition & 12 & 6.0 & 19 & 9.7 & 15 & 11.5 & 21 & 15.8 & 0.13 \\
\hline Others (specify) & 6 & 3.0 & 5 & 2.6 & 5 & 3.8 & 4 & 3.0 & 0.04 \\
\hline Total & 200 & 100 & 195 & 100 & 131 & 100 & 133 & 100 & 1.32 \\
\hline
\end{tabular}

Source: Authors' fieldwork (2017).

\section{Findings}

The findings from the analyses reveal that there exist significant relationship between market orientation practices and the performance of a hotel especially with respect to customer satisfaction, retention of old customer and enhanced patronage.

It was also observed that the size of a hotel do not influence the market orientation practices adopted by the hotel. The market orientation practices did not differ significantly based on the size of the hotel as the organizational capability is put at maximum use. The implication of this finding is that hotels irrespective of their size practice some form of market orientation.

However, it was found that the age of hotel do influence market orientation practices. While there are improvements in the market orientation practices adopted by hotel as they advanced in age in some of the sample selected, majority showed no significant relationship between the age of hotel and market orientation practices adopted.

The findings of this study validate the long-held belief that market orientation is a critical success factor for business performance. This means that hotels can improve their performance through the adoption of market orientation. This implies that hotels wishing to satisfy their customers better and outperform their competitors need to constantly monitor their behavior and internal processes.

\section{Conclusion}

The current research has extended the literature of market orientation and performance of hotels in several ways. First, the result of this research suggested 
that market orientation practices adopted by hotels have a positive and significant effect on hotel performance. This finding is consistent with several prior empirical findings that market orientation influences performance. Second, the study moved beyond investigating the market orientation and performance relationship to examine if there are differences between market orientation practices and size as well as the age of a hotel. The size of a hotel is critical in the hotel industry. One of the parameters for hotel rating is the size. In this study, the hotels investigated were drawn from 4 hotel rating categorizations available in the study area. It was found that size does not influence market orientation. Therefore, a major contribution of this study is that both small and large hotels can practice market orientation. The idea that large businesses may have more resources to practice market orientation is not justified in this study. It was also established that the age of a hotel does influence market orientation. This implies that as the hotels get older, they tend to understand their customers better and they are able to satisfy them than when they were younger. This study provides insights to researchers, practitioners and managers in the hotel industry on the importance of market orientation. It also indicates that hotel managers should create and maintain market orientation practices in order to attain superior performance.

\section{References}

[1] Ram, S. and Pradeep, G. (2001) The Market Orientation-Performance Relationship in the Context of a Developing Economy: An Empirical Analysis. Journal of Business Research, 53, 1-13. https://doi.org/10.1016/S0148-2963(99)00109-5

[2] Mohammed, A.M. (2011) Market Orientation and Business Performance among SMEs in Ghana. International Business Research, 4, 241-251.

[3] Ekaterina, P. and Utz, D. (2014) The Impact of Market Orientation on Business Performance-The Case of Tatarstan Knowledge-Intensive Companies (Russia). Problems and Perspectives in Management, 12, 225-231.

[4] Jawad, H., Fayaz, A.S. and Shoaib, Ch.A. (2016) Market Orientation and Organizational Performance in Small and Medium Sized Enterprises: A Conceptual Approach. City University Research Journal, 6, 166-180.

[5] Osuagwu, L. (2006) Market Orientation in Nigerian Companies. Marketing Intelligence \& Planning, 24, 608-631. https://doi.org/10.1108/02634500610701681

[6] Goldman, A. and Grinstein, A. (2010) Stages in the Development of Market Orientation Publication Activity. European Journal of Marketing, 44, 1384-1409. https://doi.org/10.1108/03090561011062899

[7] Kohli, A.K. and Jaworski, B.J. (1990) Market Orientation: The Construct, Research Propositions, and Managerial Implications. Journal of Marketing, 54, 1-18. https://doi.org/10.2307/1251866

[8] Narver, J.C. and Slater, S.F. (1990) The Effect of Market Orientation on Business Profitability. Journal of Marketing, 54, 20-35. https://doi.org/10.2307/1251757

[9] Ruekert, R.W. (1992) Developing a Market Orientation: An Organizational Strategy Perspective. International Journal of Research in Marketing, 9, 225-245. https://doi.org/10.1016/0167-8116(92)90019-H 
[10] Raju, P.S., Lonial, S.C. and Gupta, Y.P. (1995) Market Orientation and Performance in the Hospital Industry. Journal of Health Care Marketing, 15, 34-41.

[11] Greenley, G.E. (1995) Market Orientation and Company Performance: Empirical. Evidence from UK Companies. British Journal of Management, 6, 1-13. https://doi.org/10.1111/j.1467-8551.1995.tb00082.x

[12] Bhuian, S.N. (1997) Exploring Market Orientation in Banks: An Empirical Examination in Saudi Arabia. The Journal of Services Marketing, 11, 317-328. https://doi.org/10.1108/08876049710176006

[13] Deshpande, R., Farley, J.U. and Webster, F.E. (1993) Corporate Culture, Customer Orientation, and Innovativeness in Japanese Firms: A Quadrad Analysis. Journal of Marketing, 57, 23-37. https://doi.org/10.2307/1252055

[14] Pelham, A.M. and Wilson, D.T. (1996) A Longitudinal Study of the Impact of Market Structure, Organization Structure, Strategy and Market Orientation Culture on Dimensions of Small-Organization Performance. Journal of the Academy of Marketing Science, 24, 27. https://doi.org/10.1007/BF02893935

[15] Appiah-Adu, K. (1997) Market Orientation and Performance: Do the Findings Established in Large Firms Hold in the Small Business Sector? Journal of Euromarketing, 6, 1-26. https://doi.org/10.1300/J037v06n03_01

[16] Gray, B., Matear, S., Boshoff, C. and Matheson, P. (1998) Developing a Better Measure of Market Orientation. European Journal of Marketing, 32, 884-903. https://doi.org/10.1108/03090569810232327

[17] Shapiro, B.P. (1988) What the Hell Is Market Oriented? Harvard Business Review, 66, 119-125.

[18] Ellis, P.D. (2006) Market Orientation and Performance: A Meta-Analysis and Cross-National Comparisons. Journal of Management Studies, 43, 1089-1107. https://doi.org/10.1111/j.1467-6486.2006.00630.x

[19] Pelham, A.M. (1997) Market Orientation and Performance: The Moderating Effects of Product and Customer Differentiation. Journal of Business and Industrial Marketing, 12, 276-296,

[20] Oczkowski, E. and Farrell, M.A. (1998) Discriminating between Measurement Scales Using Non-Parametric Tests and Two Stage Least Squares Estimators: The Case of Market Orientation. International Journal of Research in Marketing, 15, 349-366. https://doi.org/10.1016/S0167-8116(98)00007-X

[21] Julian, C.C., Mohamad, O., Ahmed, Z.U. and Sefnedi, S. (2014) The Market Orientation-Performance Relationship: The Empirical Link in Export Ventures. Thunderbird Business Review, 56, 97-110. https://doi.org/10.1002/tie.21598

[22] Kohli, A.K., Jaworski, B.J. and Kumar, A. (1993) MARKOR: A Measure of Market Orientation. Journal of Marketing Research, 30, 467-477. https://doi.org/10.2307/3172691

[23] Shehu, A.M. and Mahmood, R. (2014) The Relationship between Market Orientation and Business Performance of Nigerian SMEs: The Role of Organizational Culture. International Journal of Business and Social Science, 9, 159-167.

[24] Amalia, P., Ionu, P. and Cristian, N. (2008) Market Orientation: An Interdisciplinary and Complex Concept. The Journal of the Faculty of Economics, 1055-1059.

[25] Awwad, M.S. and Agti, D.A.M. (2011) The Impact of Internal Marketing on Commercial Banks Market Orientation. International Journal of Bank Marketing, 29, 308-332. https://doi.org/10.1108/02652321111145943

[26] Deshpande, R. and Farley, J.U. (1999) Executive Insights: Corporate Culture and 
Market Orientation-Comparing Indian and Japanese Firms. Journal of International Marketing, 7, 111-127.

[27] Asikhia, U.O. (2010) Customer Orientation and Firm Performance among Nigerian Small and Medium Scale Businesses. International Journal of Marketing Studies, 2, 197-212. https://doi.org/10.5539/ijms.v2n1p197

[28] Taleghani, K.H. and Tayebi, A. (2013) Relationship between Customer Relationship Management and Marketing Performance. Journal of Business Management Perspective, 34, 109-123.

[29] Hilman, H. and Kaliappen, N. (2014) Strategic Role of Customer Orientation in Differentiation Strategy and Organizational Performance Nexus: A Partial Least Square (PLS) Approach. Research Journal of Applied Sciences, Engineering and Technology, 7, 4150-4156. https://doi.org/10.19026/rjaset.7.780

[30] Ramesh, R.S. and Ramesh, S. (2014) Impact of Market Orientation on SMEs Business Performance: An Empirical Study of Selected SMEs in Bangalore. International Journal of Research in Management, Social Science and Technology, 8, 1-13.

[31] Kai, C. and Fan, W.X. (2010) The Effects of Market Orientation on Performance in Property Service Industry. International Conference on Management and Service Science (MASS), Wuhan, 24-26 August 2010, 4050-4053.

[32] Kaliappen, N. and Hilman, H. (2013) Enhancing Organizational Performance through Strategic Alignment of Cost Leadership Strategy and Competitor Orientation. Middle-East Journal of Scientific Research, 18, 1411-1416.

[33] Lopez, S.P., Peon, J.M.M. and Ordas, C.J.V. (2005) Managing Knowledge: The Link between Culture and Organizational Learning. Journal of Knowledge Management, 8, 93-104. https://doi.org/10.1108/13673270410567657

[34] Murray, J.Y., Gao, G.Y. and Kotabe, M. (2011) Market Orientation and Performance of Export Ventures: The Process through Marketing Capabilities and Competitive Advantages. Journal of the Academy of Marketing Science, 39, 252-269. https://doi.org/10.1007/s11747-010-0195-4

[35] Chee-Hua, C., May-Chiun, L. and Ramayah, T. (2013) Market Orientation and Organizational Performance: The Moderating Role of Service Quality. Sage Journal, 3, $1-14$.

[36] Ministry of Tourism and Sports (2011) National Tourism Development Plan of 2012-2016. Government Gazette, 128, 1-5.

[37] State Ministry of Culture and Tourism (2016) The Tourism Situation Summary 2016. Tourism Statistic 2016. http://tourism.go.th/uploads/Stat/22950.pdf

[38] Yamane, T. (1967) Elementary Sampling Theory. Prentice-Hall, Inc., Englewood Cliffs. 


\section{Appendix}

\section{QUESTIONNAIRE}

\section{SECTION A: Hotel Profile}

1) Name of Hotel:

2) Year of Establishment: Below 5 years [ ] 5 - 10 years [ ] 11 - 20 years [ ] 20 years and above [ ]

3) No. of Rooms available for guest in Hotel: Below 50 [ ] 50 - 100 [ ] 101 150 [ ] $151-200$ [ ] 201 and above [ ]

4) Gender: Male [ ] Female [ ]

5) How many years have you been working in the Hotel? 0 - 5 Years [ ] 6 - 10 [ ]Years [ ] 11 Years \& above [ ]

SECTION B: Market Orientation Practices in the Hotel

6) Please indicate by ticking the market orientation practice(s) that your hotel has adopted:

a) Customer's feedback form [ ]

b) Suggestion Box [ ]

c) Use of Social media [ ]

d) Online Booking channel [ ]

e) Complimentary Breakfast Buffet [ ]

f) Free daily newspaper [ ]

g) Free Internet Services [ ]

h) Promotions [ ]

i) Recognition [ ]

j) Others (specify)

7) How often do customers benefit from these packages? Daily Weekends Monthly Yearly
a) Customer's feedback form
[ ]
b) Suggestion Box
[ ] [ ]
[ ] [ ]
c) Use of Social media
[ ] [ ]
[ ] [ ]
d) Online Booking channel
e) Complimentary Breakfast Buffet [
f) Free daily newspaper

[ ] [ ]
g) Free Internet Services

[ ] [ ]
h) Promotions

[ ] [ ]
i) Recognition
i) Recognition

8) To what extent does your hotel provide the following using the scale below?

$1=$ To a very large extent

$2=$ To a large extent

$3=$ Undecided

$4=$ Often

$5=$ Rarely 
$6=$ Never
a) Customer's feedback form
b) Suggestion Box
[ ] [ ] [ ] [ ] [ [] []
c) Use of Social media
[ ] [ ] [ ] [ ] [ [ [ ]
d) Online Booking channel
[ ] [ [ [ [ ] [ ] [ [ [ ]
e) Complimentary Breakfast Buffet
$\left[\begin{array}{llllll}] & {[]} & {[}\end{array}\right]\left[\begin{array}{lll}] & {[]}\end{array}\right.$
f) Free daily newspaper
[ ] [ ] [ ] [ ] [ [ [ ]
g) Free Internet Services
[ ] [ [ [ [ ] [ ] [] []
h) Promotions
[ ] [ ] [ ] [ ] [ [ [ ]
i) Recognition
[ ] [ [ ] [ ] [ ] [ [ [ []
j) Others (specify)
[ ] [ ] [ ] [ ] [ ] []

$\begin{array}{llllll}1 & 2 & 3 & 4 & 5 & 6\end{array}$

9) Are the views of customers incorporated in these packages?

a) Yes [ ] b) No [ ]

10)Do you think these packages are adequate enough to motivate customers revisit the hotel?

a) Yes [ ] b) No [ ]

\section{SECTION C: Hotel Performance}

11)In what ways do these packages influence Customer?

$(1=$ To a very large extent; $2=$ To a large extent; 3 = Undecided; $4=$ Often; $5=$ Rarely; $6=$ Never $)$
a) Repeat Customer's patronage
b) Retention of old Customers
[ ] [ ] [ [ [ [ ] [ [ [ ]
c) Friendliness of customers

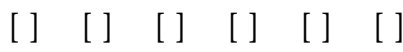
d) Enhanced patronage

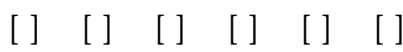
e) Customers satisfaction
$\left[\begin{array}{lllllll}] & {[} & {[} & {[} & {[]} & {[]} & {[]}\end{array}\right.$

$\begin{array}{llllll}1 & 2 & 3 & 4 & 5 & 6\end{array}$

12)What is the effect of these packages on hotel output?

Excellent [ ] Very High [ ] High [ ] Cannot tell [ ]

13)Would the hotel be able to achieve the same level of output if these packages were not introduced or were withdrawn by management? a) Yes [ ] b) No [ ]

14)To what extent do you think these packages affect hotel's performance in the following areas: $(1=$ To a very large extent; $2=$ To a large extent; $3=$ Undecided; 4 = Often; 5 = Rarely; $6=$ Never)
a) Profitability
b) Patronage
[ ] [ [ ] [ ] [ [ ] [ ] [ ]
c) Room usage
[ ] [ [ [ [ ] [ [ [ [ ] [ ]
d) Customers retention
$\left[\begin{array}{llllll}] & {[]} & {[}\end{array}\right]\left[\begin{array}{lll}] & {[]}\end{array}\right.$
e) Staff Strength
$\left[\begin{array}{llllll}] & {[}\end{array}\right]\left[\begin{array}{lll}] & {[}\end{array}\right]$
f) Return on investment
[ ] [ ] [ ] [ ] [ [ [ ]
[ ] [ ] [ ] [ ] [ ] [ ]

$\begin{array}{llllll}1 & 2 & 3 & 4 & 5 & 6\end{array}$ 